\title{
Application of egg powder in diets and its effect on serum parameters of juvenile rainbow trout
}

\author{
Gülüzar TUNA KELEŞTEMUR ${ }^{1, *}$, Neslihan KELEŞTEMUR ${ }^{2}$, \\ A. Atilla USLU $\mathbf{U}^{3}$ \\ ${ }^{1}$ Fisheries Faculty, Firat University, 23119, Elazig, Turkey \\ ${ }^{2}$ Firat University Health Services Vocational High School Elazig, Turkey \\ ${ }^{3}$ Aquaculture Research Institute, Elazlg, Turkey \\ Geliş Tarihi (Received Date): 23.03.2021 \\ Kabul Tarihi (Accepted Date): 15.09.2021
}

\begin{abstract}
In our study, the effect of dietary supplemented with $16.5 \%, 27.5 \%, \% 38.5 \%, 63.2 \%$ (respectively diet group; $Y^{1}, Y^{2}, Y^{3}, Y^{4}$ ) egg powder instead of fish meal on blood (ions, lipids, proteins) parameters of rainbow trout were determined. Fish were fed with different diets containing egg powder, and control diet (without supplemented) for 12 weeks. The Oneway ANOVA test results showed that serum lipids, protein and ions levels were affected by dietary supplementation egg powder. Serum glucose level was significantly decreased in $Y^{4}$ group $(p<0.05)$. Serum TP level was not statistically different among research groups ( $p>0.05)$. Serum creatinine level was significantly increased $Y^{3}$ and $Y^{4}(p>0.05)$ diet groups. Serum uric acid, BUN and urea levels were increased in $Y^{1}, Y^{2}, Y^{3}, Y^{4}$ diet groups compared to control groups $(p<0.05)$. The highest $M g$ levels were determined in $Y^{3}$ group $(p<0.05)$. Besides, $M g$ and $P$ levels were decreased in particular control and $Y^{4}$ groups $(p<0.05)$ according to other diet groups. However, it is concluded that the value of lipid in blood showed an increasing tendency with the increasing percent in diet egg powder.
\end{abstract}

Keywords: Rainbow trout, diet, animal protein source, egg powder, serum parameters

\footnotetext{
*Gülüzar TUNA KELEŞTEMUR, gkelestemur@ firat.edu.tr, https://orcid.org/0000-0001-8581-4385

Neslihan KELEŞTEMUR, nkelestemur@ firat.edu.tr, https://orcid.org/0000-0002-1449-8072

Ali Atilla USLU, aliatillauslu@gmail.com, https://orcid.org/0000-0002-1585-4207
} 


\section{Diyetlerde yumurta tozu uygulaması ve yavru gökkuşağ 1 alabalıklarının serum parametreleri üzerine etkileri}

\section{$\ddot{\mathbf{O z}}$}

Bu çalışmada, yavru gökkuşă̆l alabalıklarının dietlerine balık unu yerine \% 63,2, $\% 16,5, \% 27,5, \% 38,5, \% 63,2$ (strasiyla diet gruplarl; $Y^{1}, Y^{2}, Y^{3}, Y^{4}$ ) oranlarinda yumurta unu ilavesinin bazı kan parametre değerleri (lipit, protein ve iyon) üzerine olan etkileri araştırlldı. Balıklar 12 hafta süre ile yumurta unu içeren 4 farkl yem ve bazal diet ile beslendi. Oneway ANOVA test sonuçlarl, balıkların serum lipit, protein ve iyon seviyelerinin yumurta unu katkıl dietlerden etkilendiğini gösterdi. Diğer gruplarla klyaslandı̆̆ında serum glucose değeri $Y^{4}$ grubunda önemli oranda azaldı $(p<0,05)$. Araştırma grupları arasında serum TP değerleri istatistiksel olarak önemli $(p>0,05)$ değildi. Serum kreatinin değerleri $Y^{3}$ ve $Y^{4}$ gruplarında önemli oranda arttı $(p<0,05)$. Serum urik asit, BUN ve üre değerleri $Y^{1}, Y^{2}, Y^{3}, Y^{4}$ diyet gruplarında diğer gruplara göre önemli oranda arttı $(p>0,05)$. Serum $M g$ ve $P$ değerleri $Y^{3}$ grubunda önemli oranda etkilendi $(p<0.05)$. En yüksek $M g$ değeri $Y^{3}$ grubundan elde edildi $(p<0,05)$. Bunun yanısıra, serum $\mathrm{Mg}$ and $P$ değerleri kontrol ve $Y^{4}$ gruplarında diğer gruplara göre arttı $(p<0,05)$. Bununla birlikte, serum lipit seviyelerinin balık diyetinde yumurta unu artış yüzdesiyle birlikte artma ĕgilimi gösterdiği belirlendi.

Anahtar kelimeler: Gökkuşağl alabalı̆̆l, diyet, hayvansal protein, yumurta unu, serum parametreleri

\section{Introduction}

Salmonids and trout are high-value carnivors fish species that are raised in intensive farming systems, where they are given extruded feeds that are rich in energy and highquality protein [1]. A proposal has been made by The National Organics Standards Board (NOSB) to limit the use of fishmeal and oil in organically certified aquaculture, with the aim of phasing them out within 12 years [2]. Economic and ethical concerns are the main factors driving these changes, which will affect the diet formulated for carnivorous fish. The scarcity of the traditional high-quality feed components, such as fish meal, along with increasing demand from the burgeoning aquacultural sector, are driving prices upwards [3]. Fish meal (FM) and other animal protein sources are relatively expensive, and there are issues with supply and variable quality [4]. Commercial aquatic feeds have traditionally favored FM as the main protein source owing to its high protein content and balanced essential amino acid (EAA) profile, as well as being rich in essential fatty acids, digestible energy, minerals, and vitamins [5, 6]. Soybean meal is a common alternative to animal protein sources thanks to its consistent nutritional composition, reasonably balanced amino acid profile, availability, and economical price. In additionally, its antinutrient content, imbalanced amino acid profile, and poor palatability mean it is not suitable for wider use. Accordingly, for the continued development of aquaculture based on sustainable food resources, basic knowledge on the physiological consequences of a total or partial replacement of fish meal by alternative protein sources is needed [7]. Eggs are very nutrient-dense: they are a good source of high-quality nutrient, such as protein and contain significant levels of 
essential vitamins and minerals. Hasler (2000) and many researchers reported that people who eat egg are more likely than non-egg-eaters to have diets containing adequate levels of essential nutrients. Furthermore, eggs are cheap, convenient, easy to prepare, and easy to consume, and they are key to many well-known recipes. Eggs are also known to contain certain "functional" components whose health benefits go beyond basic nutrition. However, research on these "functional" components is still ongoing and none of the purported health benefits have been demonstrated conclusively [8]. Physiological state control in fish, focused on biochemical examinations of the blood, is an integral part of the complex methods of determining the health of the fish and at the same time, plays a role in feeding experiments in testing diets of different composition or testing the properties of substances having a specific effect $[9,10,11,12]$.

In the current study, the objective was to evaluate the use of egg powder to completely or partially replace fish meal in feed for juvenile rainbow trout by examining the serum proteins, ions, and lipids. In this study, the importance of formulation of sustainable and cost-effective feeds for juvenile fish.

\section{Materials and methods}

\subsection{Fish material and experimental design}

The study was carried out in the Keban Dam Lake General Directorate of the State Hydraulic Works Laboratory (Elazig, TURKEY). After a period of acclimatization, fish were randomly selected and stocked. A total of 450 juvenile rainbow trout (Oncorhynchus mykiss) with initial weight of $16.39 \pm 0.32 \mathrm{~g}$ and average total length of $12.22 \pm 0.06 \mathrm{~cm}$ were distributed into fifteen fiberglass tanks $(200 \mathrm{~cm} \times 40 \mathrm{~cm} \times 40 \mathrm{~cm})$ at a density of 30 fish per tank. We applied a five experimental design (five diet group $\times$ three replicate groups). Before starting the investigation, the dissolved oxygen level in the tank was allowed to reach $7.6 \mathrm{mg} / \mathrm{L}$. The levels of water dissolved oxygen and temperatures were recorded by a portable YSI Probe (55 Model 51/12). The water was 8.8-9.4 ${ }^{\circ} \mathrm{C}$ at $\mathrm{pH} 8.4$ throughout the experiment. Every 2 weeks, the fish were anesthetized ( $15 \mathrm{mg} / \mathrm{l}$ quinaldine) for body weights measured.

\subsection{Diets}

The following experimental diets were prepared: $\mathrm{Y}^{1}, \mathrm{Y}^{2}, \mathrm{Y}^{3}, \mathrm{Y}^{4}$, supplemented with $16.5 \%, 27.5 \%, 38.5 \%$, and $63.2 \%$ egg powder instead of fish meal, respectively, and a control diet (C) (diet not supplemented with egg powder) (Table 1). The basal composition of the experimental diets was based on the National Research Council specifications (NRC, 1993) [13]. The dry matter ( $105^{\circ} \mathrm{C}$, overnight), ash $\left(650{ }^{\circ} \mathrm{C}, 6\right.$ $\mathrm{h}$ ), crude protein (nitrogen $\times 6.25$ ), ether extract, and crude fiber contents of the diets and egg powder (Table 2) were determined according to the AOAC methods [14, 15, $16,17]$. The fish were fed thrice daily throughout the study with a daily feed allowance of $3 \%$ of their body weight per day. The eggs (whole egg) were beaten and dried in a thin layer in the oven at $150{ }^{\circ} \mathrm{C}$ for 50 minutes. It was cooked in a thin layer in the oven then this dried mixture was crushed into powder [18]. 
Table 1. Composition (\%) and proximate analysis (\%, dry matter) of the experimental.

\begin{tabular}{lccccc}
\hline Ingredients & $\mathbf{C}$ & $\mathbf{Y}^{\mathbf{1}}$ & $\mathbf{Y}^{\mathbf{2}}$ & $\mathbf{Y}^{\mathbf{3}}$ & $\mathbf{Y}^{\mathbf{4}}$ \\
\hline Fish meal & 55 & 42 & 36 & 29.4 & - \\
Egg powder & - & 16.5 & 27.5 & 38.5 & 63.2 \\
Soybean meal & 13.3 & 13.3 & 13.3 & 13.3 & 13.3 \\
Wheat meal & 12 & 12.5 & 9.5 & 8.6 & 10.8 \\
Fish Oil & 12 & 8 & 6 & 2,5 & - \\
Boncalit & 5 & 5 & 5 & 5 & 10 \\
Antioksidan (a) & 0.1 & 0.1 & 0.1 & 0.1 & 0.1 \\
Vitamin Karmas1 & 1 & 1 & 1 & 1 & 1 \\
(b) & & & & & \\
Mineral Karmas1 & 1 & 1 & 1 & 1 & 1 \\
(c) & & & & & \\
C Vitamini & 0.6 & 0.6 & 0.6 & 0.6 & 0.6 \\
Toplam & $\mathbf{1 0 0}$ & $\mathbf{1 0 0}$ & $\mathbf{1 0 0}$ & $\mathbf{1 0 0}$ & $\mathbf{1 0 0}$ \\
\hline Proximate composition and Total energy (kcal/kg) & & \\
\hline $\begin{array}{l}\text { Crude protein } \\
\text { Crude fat }\end{array}$ & 44.73 & 43.59 & 43.13 & 43.44 & 39.85 \\
Ash & 17.81 & 17.44 & 18.44 & 18.78 & 19.54 \\
N-free matter & 12.17 & 12.05 & 11.14 & 12.34 & 10.12 \\
Mousture & 16.49 & 18.12 & 18.79 & 16.74 & 22.09 \\
\hline a) Buten & 8.8 & 8.5 & 8.5 & 8.7 & 8.4 \\
\hline
\end{tabular}

a) Butilen Hydroxytoluene (BHT); $125.000 \mathrm{mg} / \mathrm{kg}(\mathrm{b})$ Vitamin premix (IU or mg/kg dry diet): Vitamin A; 12.000.000 IU, vitamin D3; $120 \mathrm{IU}$, vitamin E; $30.000 \mathrm{IU}$, vitamin K3; $0.9 \mathrm{mg}$, vitamin B1; $1.2 \mathrm{mg}$, vitamin B2; $1.5 \mathrm{mg}$, vitamin B6; $1.2 \mathrm{mg}$, vitamin B12; $0.003 \mathrm{mg}$, niacin; $12 \mathrm{mg}$, cal-D- pant.; $2.4 \mathrm{mg}$, folik asit; $1000 \mathrm{IU}$, D biotin; $0.03 \mathrm{mg}$, inositol; $15 \mathrm{mg}$, vitamin C; $15 \mathrm{mg}$, antioksidant; $0.75 \mathrm{mg}$, choline cloride; 72 mg.(c)Mineral premix (mg/kg dry diet); Mn 80.000, Fe 35.000, Zn 50.000, Cu 5.000, I 2.000, Co 400, Se 150

Table 2. Proximate analysis (\%) and total energy (kcal) of the whole egg powder [19].

\begin{tabular}{lc}
\hline Proximate composition & \\
\hline Crude protein $(\mathrm{g} / 100 \mathrm{~g})$ & 45.2 \\
Crude fat $(\mathrm{g} / 100 \mathrm{~g})$ & 38.3 \\
Utilizable carbohydrate $(\mathrm{g} / 100 \mathrm{~g})$ & 11.8 \\
Mousture $(\mathrm{g} / 100 \mathrm{~g})$ & 3.6 \\
Energy $(\mathrm{kcal} / 100 \mathrm{~g})$ & 572.8 \\
\hline
\end{tabular}




\subsection{Blood sampling}

Blood samples were taken from the caudal veins of 10 juvenile trout in each tank after anesthesia (15 mg/L quinaldine) at the end of the experiment, The blood specimens were centrifuged at $2500 \mathrm{rpm}$ for $10 \mathrm{~min}$ to obtain serum, which was then stored at -20 ${ }^{\circ} \mathrm{C}$ for two weeks. Plastic tubes with red-capped were used for serum samples [20]. The blood samples were analyzed in the First University Health Services Vocational High School Laboratory using a Roche Hitachi Cobas Autoanalyzer 6000 device [21, 22].

\subsection{Statistical methods}

The results are presented as mean \pm standard error of the mean (SE). Differences among the means were compared using one-way ANOVA followed by the Tukey test (SPSS 19 Programe).

\section{Results}

Serum total protein (TP), urea, uric acid, creatinine, BUN (blood urea nitrogen), urea and glucose values of juvenile trout fed with the various experimental diets are determined (Table 2). The statistical test showed that blood protein levels of juvenile fish were considerably affected by dietary different supplementation of egg powder instead of fish meal. Serum glucose level was significantly decreased in $\mathrm{Y}^{4}$ group $(\mathrm{p}<0.05)$. Serum TP level was not statistically different among research groups $(p>0.05)$. Serum creatinine level was significantly increased $\mathrm{Y}^{3}$ and $\mathrm{Y}^{4}(\mathrm{p}>0.05)$ diet groups. Serum uric acid, BUN and urea levels was increased in $\mathrm{Y}^{1}, \mathrm{Y}^{2}, \mathrm{Y}^{3}, \mathrm{Y}^{4}$ diet groups compared to control groups ( $>0.05)$, the highest BUN levels were determined in $\mathrm{Y}^{4}$ group $(\mathrm{p}<0.05)$.

Table 3. Serum glucose, TP, uric acid, creatinine, BUN, urea levels of the experimental groups at the end of the experiment $\left(\mathrm{mg} \mathrm{dL}^{-1}\right)$.

\begin{tabular}{cccccc}
\hline $\begin{array}{c}\text { Blood } \\
\text { Parameters }\end{array}$ & $\mathbf{C}$ & $\mathbf{Y}^{\mathbf{1}}$ & $\mathbf{Y}^{\mathbf{2}}$ & $\mathbf{Y}^{\mathbf{3}}$ & $\mathbf{Y}^{\mathbf{4}}$ \\
\hline Glucose & $88 \pm 1.11^{\mathrm{a}}$ & $87 \pm 1.35^{\mathrm{a}}$ & $85 \pm 1.17^{\mathrm{a}}$ & $74 \pm 1.12^{\mathrm{a}}$ & $56 \pm 2.19^{\mathrm{b}}$ \\
TP & $2.9 \pm 0,56$ & $2.9 \pm 0.35$ & $3.0 \pm 0.17^{-}$ & $3.5 \pm 0.71$ & $3.5 \pm 0.15$ \\
Uric Acid & $0.67 \pm 0.01^{\mathrm{b}}$ & $1.77 \pm 0.05^{\mathrm{a}}$ & $1.84 \pm 0.03^{\mathrm{a}}$ & $1.86 \pm 0.01^{\mathrm{a}}$ & $\begin{array}{c}1.97 \pm 0.03 \\
\mathrm{a}\end{array}$ \\
Creatinine & $0.12 \pm 0.12^{\mathrm{b}}$ & $0.19 \pm 0.14^{\mathrm{b}}$ & $0.46 \pm 0.17^{\mathrm{b}}$ & $1.41 \pm 0.11^{\mathrm{a}}$ & $\begin{array}{c}1.75 \pm 0.19 \\
\mathrm{a}^{\mathrm{a}}\end{array}$ \\
BUN & $2 \pm 0.16^{\mathrm{c}}$ & $3 \pm 0.27^{\mathrm{b}}$ & $3 \pm 0.45^{\mathrm{b}}$ & $3.5 \pm 0.26^{\mathrm{b}}$ & $5 \pm 0.43^{\mathrm{a}}$ \\
Urea & $1.7 \pm 0.14^{\mathrm{c}}$ & $3.2 \pm 0.13^{\mathrm{b}}$ & $4.3 \pm 0.13^{\mathrm{a}}$ & $4.9 \pm 0.16^{\mathrm{a}}$ & $5.7 \pm 0.15^{\mathrm{a}}$ \\
\hline
\end{tabular}

${ }^{a-c}$ Means in the same line with different subscript are significant $(\mathrm{p}<0.05),(n=3)$.

Statistical results showed that serum electrolyte levels of juvenile fish were considerably affected by dietary different supplementation of egg powder. The serum values of calcium $(\mathrm{Ca})$, potassium $(\mathrm{K})$, magnesium $(\mathrm{Mg})$, sodium $(\mathrm{Na})$, phosphorus $(\mathrm{P})$ potassium $(\mathrm{K})$, and chloride $(\mathrm{Cl})$ are showed in Table 3. Serum $\mathrm{Mg}$ and $\mathrm{P}$ level were significantly affected by $\mathrm{Y}^{3}$ group $(\mathrm{p}<0.05)$. The highest $\mathrm{Mg}$ levels were determined in 
$\mathrm{Y}^{3}$ group $(\mathrm{p}<0.05)$. Besides, $\mathrm{Mg}$ and $\mathrm{P}$ levels were decreased in particular control and $\mathrm{Y}^{4}$ group $(\mathrm{p}<0.05)$ according to other diet groups. The lowest $\mathrm{Na}$ levels were determined in $\mathrm{Y}^{4}$ group $(\mathrm{p}<0.05)$. Serum $\mathrm{Ca}, \mathrm{K}$ and $\mathrm{Cl}$ levels were not statistically different among all dietary treatments $(\mathrm{p}>0.05$

Table 4. Serum electrolyte levels of experimental groups at the end of the experiment.

\begin{tabular}{|c|c|c|c|c|c|}
\hline $\begin{array}{c}\text { Blood } \\
\text { Parameters }\end{array}$ & $\mathbf{C}$ & $\mathbf{Y}^{1}$ & $\mathbf{Y}^{2}$ & $\mathbf{Y}^{3}$ & $Y^{4}$ \\
\hline $\operatorname{Mg}\left(\mathrm{mgdL}^{-}\right)$ & $0.94 \pm 0.51^{b}$ & $1.19 \pm 0.25^{b}$ & $1.22 \pm 0.23^{b}$ & $2.36 \pm 0.51^{\mathrm{a}}$ & $0.55 \pm 0.39^{b}$ \\
\hline $\mathrm{Ca}\left(\mathrm{mmolL}^{-}\right)$ & $2.9 \pm 0.11$ & $3.4 \pm 1.45$ & $3.6 \pm 2.17$ & $3.9 \pm 0.34$ & $2.4 \pm 0.79$ \\
\hline $\mathrm{Na}\left(\mathrm{mmolL}^{-}\right)$ & $150 \pm 0.17^{\mathrm{a}}$ & $152 \pm 0.22^{\mathrm{a}}$ & $153 \pm 0.74^{\mathrm{a}}$ & $155 \pm 0.54^{\mathrm{a}}$ & $139 \pm 0.67^{b}$ \\
\hline $\mathrm{K}\left(\mathrm{mmolL}^{-}\right)$ & $3.4 \pm 0.11$ & $3.7 \pm 0.27$ & $4.4 \pm 0.23$ & $5.6 \pm 0.47$ & $3.1 \pm 0.39$ \\
\hline $\mathrm{Cl}\left(\mathrm{mmolL}^{-}\right)$ & $151 \pm 0,16$ & $152 \pm 0.45$ & $156 \pm 0.17$ & $156 \pm 0.44$ & $156 \pm 0.69$ \\
\hline $\mathrm{P} \quad\left(\mathrm{mgdL} \mathrm{L}^{-}\right)$ & $3100 \pm 19.1^{\mathrm{d}}$ & $3300 \pm 25.3^{\mathrm{c}}$ & $3500 \pm 21.1^{\mathrm{b}}$ & $3700 \pm 26.1^{\mathrm{a}}$ & $3000 \pm 32.2^{\mathrm{d}}$ \\
\hline
\end{tabular}

According to the statistical test, TG, VLDL, CHOL values of serum were increased by dietary different supplementation of egg powder (Table 4). The highest TG level was obtained by $\mathrm{Y}^{4}$ group, the lowest $\mathrm{TG}$ level was determined by $\mathrm{C}$ and $\mathrm{Y}^{1}$ groups $(\mathrm{p}<0.05)$. The lowest VLDL and CHOL levels were determined in $\mathrm{Y}^{1}$ and the control group $(\mathrm{p}<0.05)$.

Table 5. Serum triglyceride (TG), VLDL, cholesterol (CHOL) levels of experimental groups at the end of the experiment $\left(\mathrm{mg} \mathrm{dL}^{-1}\right)$.

\begin{tabular}{cccccc}
\hline $\begin{array}{c}\text { Blood } \\
\text { Parameters }\end{array}$ & $\mathbf{C}$ & $\mathbf{Y}^{\mathbf{1}}$ & $\mathbf{Y}^{\mathbf{2}}$ & $\mathbf{Y}^{\mathbf{3}}$ & $\mathbf{Y}^{4}$ \\
\hline TG & $199 \pm 9.11^{\mathrm{c}}$ & $227 \pm 3.35^{\mathrm{c}}$ & $405 \pm 7.97^{\mathrm{b}}$ & $434 \pm 4.81^{\mathrm{b}}$ & $491 \pm 4.19^{\mathrm{a}}$ \\
VLDL & $76 \pm 3.11^{\mathrm{d}}$ & $84 \pm 4.35^{\mathrm{d}}$ & $159 \pm 8.17^{\mathrm{c}}$ & $198 \pm 5.41^{\mathrm{b}}$ & $327 \pm 5.19^{\mathrm{a}}$ \\
CHOL & $294 \pm 7.11^{\mathrm{d}}$ & $324 \pm 4.35^{\mathrm{d}}$ & $406 \pm 3.17^{\mathrm{c}}$ & $683 \pm 8.13^{\mathrm{b}}$ & $819 \pm 4.22^{\mathrm{a}}$
\end{tabular}

${ }^{a-d}$ Means in the same line with different subscript are significant $(p<0.05),(n=3)$.

\section{Discussion and conclusion}

This study has investigated the effects of egg powder on blood protein, lipid and ions values as an alternative protein source in practical diets for juvenile rainbow trout. Similarly, egg powder is as valuable as fish meal for diets. A 1996 study on eggs and nutrition confirmed that eggs have a place in a healthy diet and can help to provide good nutrition. Eggs are a highly nutritious food. Eggs are very rich in high-quality protein and are a cost-effective source of animal protein, as well as providing significant amounts of several vitamins and minerals [8]. The aquaculture industry is anticipating the development and evaluation of alternative sources of protein for use in fish feeds for 
high-value carnivorous species [3, 23]. Protein is the major structural component in the diet. Protein is required for enzymes and hormones as well as for the production of neurotransmitters, vitamins, antibodies, and other important molecules. Protein quality refers to the ability to provide nitrogen and to meet the amino acid requirements for growth, maintenance, and repair. Protein quality is based on a protein's digestibility and its amino acid profile [24]. Egg powder has been reported to be as valuable as fish meal for diets [25]. There is concern among some investigators that a diet that is high in animal protein but low in fiber could increase cardiovascular disease risk [26], and that high intake of protein intake could cause renal damage by encouraging renal hyperfiltration. To date, the debate around protein has largely been focused on protein restriction to preserve renal function in high-risk subjects, including those with preexisting renal disease or diabetes $[27,28,29]$. The current thinking is that restricted protein intake can improve some of the complications of renal failure, including renal and liver disease, hypertension, electrolyte disturbances, and metabolic acidosis, by reducing the levels of phosphates, sodium, and acid metabolites[30]. However, there is no consensus regarding how much restricting protein intake can slow the progression of renal insufficiency and how much damage is caused by higher protein intakes [25, 29].

Liver and kidney dysfunction can be identified by monitoring changes to some blood parameters. Specifically, serum cholesterol, VLDL, and triglyceride values are important biomarkers of liver function, while serum total protein, urea, uric acid, creatinine, BUN, and electrolyte levels biomarkers of renal function [28]. In the current research, the effects of feeds supplemented with different levels of egg powder on juvenile $O$. mykiss fish were investigated by determining the total protein, uric acid, creatinine, blood urea nitrogen (BUN), urea and glucose, total cholesterol, triglyceride, VLDL, Mg, Ca, Na, K, Cl, and P levels. The results of biochemical tests reported in the literature show that the lipid and protein metabolism levels of rainbow trout correspond to the lipid and protein contents in the ration, which is in agreement with the results of our study. The blood glucose for rainbow trout is affected by factors such as physical factors, chemical factors, stress, disease and diet [12, 31, 32]. In this study, the fish have decreased concentration of blood glucose fed with completely supplemented egg powder. On the other hand, TP, urea, uric acid, BUN, creatinine, VLDL, cholesterol and triglyceride levels showed increasing tendency with increasing proportion of egg powder in the diet. Similarly, some researchers reported that the inclusions of high levels of protein ad lipid in diets have quite effective for fish metabolism. [12]. Electrolyte $(\mathrm{Na}, \mathrm{K}, \mathrm{P}$, and $\mathrm{Ca}$ ) levels indicate the operation of a variety of homeostatic mechanisms in the body. Sodium, potassium and chloride play an important role in osmoregulation and homeostasis [33]. Our study it is show that high protein supplemented in a diet such as egg powder has an influence on the changes of serum ion concentration. But statistical difference was not determined among the groups in serum $\mathrm{Cl}$ and $\mathrm{Na}$ level ( $\mathrm{p}>0.05)$. In this study was determined that fish serum other electrolytes $(\mathrm{Mg}, \mathrm{Ca}, \mathrm{K}$, and $\mathrm{P})$ levels increased in rainbow trout fed on egg powder partly substituted (respectively, 16.5\%, 27.5\%, 38.5\%) with fish meal. Electrolyte levels (Mg, $\mathrm{Ca}, \mathrm{K}$, and $\mathrm{P}$ ) decreased in egg powder $63.2 \%$ supplemented diet.

This study viewed that similarly some researchers reported that the effect of diet ingredients and nutrition regime affect fish blood chemistry [34]. This research showed that diets high in animal-protein foods such as egg powder were lead to changes in serum protein, serum lipid and serum electrolyte values in juvenile rainbow trout. Experimental diets supplemented with egg powder instead of fish meal and it was determined that serum glucose levels concluded a decreasing tendency with the 
increasing percent in the fish diet but such as serum TP, urea, uric acid, BUN, creatinine protein-based levels concluded a decreasing tendency with the increasing percent in fish especially in over $30 \%$ for juvenile rainbow trout diets. When these parameters are interpreted egg powder used over $30 \%$ in the diet of juvenile fish has significantly negative effects on kidney functions. In addition, such as serum cholesterol, VLDL and triglyceride lipid-based levels concluded an increasing tendency with the increasing percent in fish especially in over $40 \%$ for juvenile rainbow trout diets. Interpreted for these results egg powder used over $40 \%$ in the diet of juvenile rainbow trout it has significant negative effects on the liver. When interpreted electrolytes one of the other kidney function biomarkers serum $\mathrm{Na}$ and $\mathrm{Cl}$ level was not different among all dietary treatments. Other electrolyte levels increased concluded an increasing tendency with the increasing percent in juvenile fish especially up to $40 \%$ while about used in $60 \%$ level has significantly decreased.

In conclusion, the result of the experiment showed that chicken egg powder can be used relatively in juvenile rainbow trout diets as other plant and animal protein source. Chicken egg powder seems to be the cheapest and easily available only protein source to replace fish meal. According to this study results, egg powder can be safely used up to $30 \%$ but when using more than $30 \%$ egg powder in juvenile trout diets, it may have significant adverse effects on the liver and kidney function of juvenile $O$. mykis's. It will make great contributions to sustainable fisheries using alternative protein sources instead of fish meal.

\section{Acknowledgements}

This study was supported by the Research Fund of Aquaculture Research Institute, Elazığg, Turkey (Project No: TAGEM/HAYSUD/2016/A11/P-01/3).

\section{References}

[1] Tacon, A.G.J., Feed ingredients for warm water fish, Fish meal and other processed Feedstuffs, Food and Agriculture Organization (FAO), Fisheries Circular No, 856, Italy, (1993).

[2] Naylor, R.L., Hardy, R.W., Bureau, D.P., Chiu, A., Elliott, A., Farrell, A.P., Forster, I., Gatlin, DM, Goldburg, R.J., Hua, K. and Nichols, P.D., Feeding aquaculture in an aera of finite resources, Proceedings of the National Academy of Sciences, United States of America, 106, 15103-15110, (2009).

[3] Brinker, A. and Reinhard, R., Fish meal replacement by plant protein substitution and guar gum addition in trout feed, Effects on feed utilization and fish quality, Aquaculture, 310, 350-360, (2011).

[4] Pratoomyot, J., Bendiksen, E.,A, Bell, J.G. and Tocher, D.R., Effects of increasing replacement of dietary fishmeal with plant protein sources on growth performance and body lipid composition of Atlantic salmon (Salmo salar L.), Society, 40(1), 113-118, (2009).

[5] Dias, J., E.C., Conceiçao, R.A., Riberio, P. and Bordes, M.P., Valente and Dinis, T.M., Practical diet with low fish-derived protein is able to sustain growth performance in gilthead seabream (Sparus aurata) during the grow-out phase, Aquaculture, 293, 255-262, (2009). 
[6] Gomez-Requenia, P., Mingarroa, M., Calduch-Ginera, J.A., Me'dabled, F., Martinc, S.A.M., Houlihanc, D.F., Kaushink S. and Perez-Sancheza, J., Protein growth performance, amino acid utilization and somatotropic axis responsiveness to fish meal replacement by plant protein sources in gilthead sea bream (Sparus aurata), Aquaculture, 232, 493-510, (2004).

[7] Hasler, C.M., The changing face of functional food, Journal American College of Nutrition, 19, 499-506, (2000).

[8] Řehulka, J. and Minařk, B., Effect of some physical and chemical characteristics of wetter on the blood indices of rainbow trout, Oncorhynchus mykiss, fed astaxanthin containing diet, Czech, Journal of Animal Sciences, 46, 413-420, (2001).

[9] Ezzat, A.A., Studies on blood characteristics of Tilapia zilli (Gervais): I. Blood cells, Journal of Fish Biology, 6(2), 1-12, (1974).

[10] Van Vuren, J.H.J. and Hatting, J., The seasonal haematology of the small-mouth yellow-fish Barbus holubi, African Zoology 11, 81-86, (1976).

[11] Kopp, R., Mareš, S.J., Lang, T. and Brabec, A., Assessment of ranges plasma indices in rainbow trout (Oncorhynchus mykiss) reared under conditions of intensive aquaculture, Zikova Acta Universitatis Agriculturae Et Silviculturae Mendelianae Brunensis, 24(6), 181-188, (2011).

[12] The Norwegian Refugee Council (NRC), Nutrient Requirements of Fish: National Research Council, Washington, D.C., National Academy Press, 114, (1993).

[13] Association of Offical Analytical Chemists (AOAC), Analyses, Official Methods of Analysis, 16 th Edn., Arlington, V.A., 113-115, (1995).

[14] Özpolat, E., Patır, B., Güran, H.Ş. and Gül, M.R., Effect of vacuum-packing method on the shellfish-life of Copoeta umbla sausages, Iranian Journal of Fisheries Sciences, 13(1), 178-184, (2014).

[15] Özpolat, E. and Patır, B., Determination of shelf-life for sausages produced from some freshwater fish using two different smoking methods, Journal of Food Safety, 36(1), 69-76, (2016).

[16] Özpolat, E. and Duman, M., Effect of black cumin oil (Nigella sativa L.) on fresh (Barbus grypus) fillets during storage at $2 \pm 1{ }^{\circ} \mathrm{C}$, Food Science and Technology, 37(1), 148-152, (2017).

[17] Abrehaa, E., Getachawa, P., Laillou, A., Chitekweb, S., Baye, K., Physicochemical and functionality of air and spray dried egg powder: implications to improving diets, International Journal of Food Properties, 24(1), 152-162, (2021).

[18] Ebring, M., Desugarization of Egg Products: Egg Science and Technology, The Haworth Press, New York, 324, (1995).

[19] Lawrence, J.B., Preanalytical variables in the coagulation laboratory, Laboratory Medicine, 34, 49-57, (2003).

[20] Karataş, F., Karatepe, M. and Baysar A., Determination of free malondialdehyde in human serum high performance liquid chromatography, Anal Biochemistry, 3(11), 76-79, (2002).

[21] Tuna keleştemur, G. and Yıldırım, I., Effect of dark period on the blood vitamin $\mathrm{c}$ and malondialdehyde levels of the juvenile rainbow trout (Oncorhynchus mykiss, W. 1792, Journal of Balıkesir University Institute of Science and Technology, 12(2), 55-60, 2010.

[22] Gatlin, D.M., Barrows, T.M., Brown, P., Dabrowski, K., Gaylord, T.G., Hardy, R.W., Herman, E., Hu, G., Krogdahl, A., Nelson, R., Overturf, K., Rust, M., 
Sealey, W., Skonberg, D., Souza, E.J., Stone, D., Wilson, R. and Wurtele, E., Expanding the utilization of sustainable plant products in aquafeeds: A review, Aquacuatic Research, 38, 551-579, (2007).

[23] Food and Nutrition Board (FNB), Dietary Reference Intakes for Energy, Carbohydrate, Fiber, Fat, Fatty Acids, Cholesterol, Protein, and Amino Acids (Macronutrients), Washington, D.C., Macronutrient and Healthful Diets, The National Academies Press, 609-696, (2002).

[24] Dawber TR, Nickerson RJ, Brand FN, Pool J., Eggs, serum cholesterol, and coronary heart disease. American Journal of Clinical Nutrition, 36, 617-625, (1982).

[25] King, A.J. and Levey, A.S., Dietary protein and renal function, Journal of Animal Society Nephrololy, 3(11), 1723-37, (1993).

[26] Higashihara, E., Horie, S., Takeuchi, T., Nutahara, K. and Aso, Y., Long-term consequence of nephrectomy, Journal of Urology, 143, 239-243, (1990).

[27] Luscombe, N.D., Clifton, P.M., Noakes, M., Farnsworth, E. and Wittert, G., Effect of a high-protein, energy-restricted diet on weight loss and energy expenditure after weight stabilization in hyperinsulinemic subjects, International Journal of Obesity Relation Metabolism Disorder, 27, 582-590, (2003).

[28] Layman, D.K., Boileau, R.A., Erickson, D.J., Painter, J.E., Shiue, H., Sather, C. and Christou, D.D., Reduced ratio of dietary carbohydrate to protein improves body composition and blood lipid profiles during weight loss in adult women, Journal of Nutrition, 133, 411-417, (2003).

[29] Kandaswamy, S., Barvithra, S., Suganya, S., Bhat, A.F., Krishnamoorthy, G. and Arunakaran, J., Effect of quercetin on haematobiochemical and histological changes in the liver of polychlorinated biphenyls-1nduced adult male wistar rats, Journal of Biomarkers, 13, 1-12, (2013).

[30] Řehulka, J. and Parova, J., Effect of diets with different lipid and protein contents on some blood and condition indices of rainbow trout, Oncorhynchus mykiss (Walbaum), Czech Journal of Animal Sciences, 45, 263-269, (2000a).

[31] Rehulka J. and Parova, J., Influence of three types of oil in diet upon some blood and condition indices of rainbow trout, Oncorhynchus mykiss (Walbaum): Czech Journal of Animal Sciences, 45, 127-132, (2000b).

[32] Casillas, E. and Simith, L.S., Effect of stress on blood coagulation an hematology in rainbow trout, $S$ gairdneri, Journal of Fish Biology, 10, 481491, (1977).

[33] Shimma, Y., Shimma, H. and Ikeda, K., Plasma Constituents of 2-Year-Old Rainbow Trout Raised with Fish Meal and SCP Combined Feeds, Bulletin of National Research Institute of Aquaculture, 47(3), 371-37, (1982). 